\title{
Correlation and Path Coefficient Analyses in Sugarcane Genotypes of Ethiopia
}

\author{
Esayas Tena ${ }^{1}$, Firew Mekbib², Amsalu Ayana ${ }^{3}$ \\ ${ }^{1}$ Sugar Corporation of Ethiopia, Research and Training, Wonji, Ethiopia \\ ${ }^{2}$ School of Plant Sciences, Haramaya University, Haramaya, Ethiopia \\ ${ }^{3}$ Integrated Seed Sector Development Ethiopia Program, Addis Ababa, Ethiopia \\ Email: *esutena11@gmail.com, firew.mekbib@gmail.com, ayana6a@yahoo.com
}

Received 5 March 2016; accepted 26 July 2016; published 29 July 2016

Copyright (C) 2016 by authors and Scientific Research Publishing Inc.

This work is licensed under the Creative Commons Attribution International License (CC BY).

http://creativecommons.org/licenses/by/4.0/

(c) (i) Open Access

\begin{abstract}
To study the relations of certain morphological and sugar quality characters with sugarcane yield, an experiment was conducted at Wonji and Metehara Sugar Estates, Ethiopia between March 2012 and October 2013. The experiment, comprising of 400 sugarcane genotypes of which 174 were local that were collected from different regional states of Ethiopia and 226 introduced, was laid out in partial balanced lattice design with two replications. Data was collected on cane yield and its components, sugar yield and sugar quality traits. ANOVA, correlation and path coefficient analysis were done. Analysis of variance revealed significant differences $(P<0.01)$ for all the characters studied. Cane yield showed strong positive and highly significant $(P<0.01)$ correlation with millable cane number $(r=0.832)$, single cane weight $(r=0.528)$, stalk height $(r=0.517)$ and sugar yield $(r=0.987)$. There was also positive significant $(P=0.05)$ correlation of tiller count and cane diameter with cane yield. Path analysis revealed the highest positive direct effect of millable cane number $(0.812)$ on cane yield followed by single cane weight $(0.682)$ and pol percent $(0.550)$. However, stalk diameter and brix percent had considerable negative direct effects and indirect positive effects through single cane weight on cane yield. Therefore, in view of their significant positive association with cane yield, indirect effects of stalk diameter and brix percent via single cane weight should be considered during selection. Genotypes should be selected on the basis of millable cane number, single cane weight and pol percent for getting higher cane and sugar yield.
\end{abstract}

\section{Keywords}

Cane Yield, Morphological Characters, Sugar Quality, Sugar Yield

*Corresponding author. 


\section{Introduction}

Sugarcane is the main source of sugar production in Ethiopia and one of the most important agro industrial crops of the world. It also boosts national economy by providing direct and indirect employment to the people in Ethiopia. Sugar per unit area is determined by the cane yield per unit area and sucrose percent in juice. These two characters are influenced by their component traits. As the demand for white sugar is increasing continuously, the cane productivity and sugar recovery has to be increased accordingly. In sugarcane, complex traits like cane yield and quality are influenced by a number of characters. These characters directly and indirectly contribute to the yield [1]. [2] emphasized that genetic diversity and location specific varieties are essential for achieving sustainable advances in productivity. Variety is the pivot and the cheapest technology for boosting cane production and productivity through sugarcane varietal improvement program and this program proceeds via choosing parents and making crosses.

Since the start the Ethiopian sugar industry has been totally dependent on importation of varieties. The varieties are of old generation and are contracted with many problems vis a vis deterioration of yield, lack of adaptability to different agro ecologies, susceptibility to disease and insect pests, etc. Currently Ethiopia is in the course of establishing sugarcane breeding program to develop varieties that suit to the different growing conditions of sugarcane growing regions. In any breeding program collection of germplasm is always the first step as it provides plant breeders with sources of useful traits. Especially collecting local germplasm would be crucial as they provide locally adapted genes for better crop improvement. Towards this effort, an exploration and collection work of local sugarcane germplasm in different geographic regions of Ethiopia has been conducted and more than 300 materials were collected [3]. Knowledge of character associations among the introduced and local genotypes is of prime importance to begin an effective breeding program. Information about the contribution of various cane and quality characters to cane yield is vital for development of new high yielding sugarcane cultivars. This could be achieved using the methods of path coefficients which partitions correlations among the traits into components of direct and indirect effects on the dependent variable [4]. These would be followed by development of selection criteria comprising the traits with high direct effects for selection of sugarcane genotypes manifesting a higher yield advantage.

The study of correlations provides the information that how strongly traits are genetically associated with one another. Thus the estimates of correlations among yield components pave the basis for selection of superior genotypes from the diverse breeding populations.

Path coefficient is an excellent means of studying direct and indirect effects of interrelated components of a complex trait [5]. Path-coefficient analysis measures the direct influence of one variable on another. Each correlation coefficient between a predictor variable and the response variable is partitioned into its component parts: the direct effect or path coefficient (a standardized partial regression coefficient) for the predictor variable and indirect effects, which involve the product of a correlation coefficient between two predictor variables with the appropriate path coefficient in the path diagram [6]. By determining the inter-relationships among yield components, a better understanding of both the direct and indirect effects of the specific components can be attained. Effects of stalk number, stalk diameter, stalk length and single cane weight on cane yield have been reported by [7]-[9].

Path analysis done by [10] showed that the number of cane stalks was the most important character with the highest direct and indirect effects on sucrose yield followed by sucrose $\%$ and stalk weight. Cane yield was found by [11] to be positively correlated with millable stalks, stalk height, internode number per stalk, and single stalk weight. They, however, noted negative association of cane yield with stalk diameter, juice pol, and purity $\%$.

Cane yield and sucrose content are two important characters for obtaining high sugar yield [12]. [13] reported that cane yield and sucrose content and their interaction were important parameters for developing superior genotypes. [14] concluded that the increase in cane yield was due to combined effect of stalks per stool, length of stalk and weight per stool. According to [15] number of stalks per stool was a major yield contributing factor followed by height and cane girth. [16] concluded that cane yield exhibited phenotypic association with stalks per stool.

[17] reported non-significant correlation between stalks per stool and cane yield. The correlation of tillers per plant with weight per stool was significant, whereas purity \%, pol \% and commercial cane sugar (CCS \%) showed negative correlation with tiller numbers. In case of sugar yield strong positive correlation was observed 
with cane yield, cane weight, tiller numbers, pol \%, CCS \% and purity \% and non-significant correlation was observed with cane girth.

Many component analyses have been performed for complex traits based on morphological and physiological characterizations [18]-[20]. [7] stated it could be more effective that yield components were selected to increase yield because of lower heritability for yield and higher heritability for yield components. However, yield is correlated with yield components in complicated ways [21] [22]. Therefore, it is imperative to reveal the genetic relationship between yield and its component traits

Plant breeders generally select for only a few traits and it is very important to know the effects of this on other important characters as well. Therefore, this experiment was conducted to study the relations of certain morphological and sugar quality characters with sugarcane yield.

\section{Materials and Methods}

The study was carried out at two sugar estates in Ethiopia. Wonji Sugar Estate is located in the Rift Valley of Ethiopia at an altitude and longitude of $8^{\circ} 31^{\prime} \mathrm{N}$ and $39^{\circ} 12^{\prime} \mathrm{E}$, respectively, with an elevation of 1550 masl. The area has a mean maximum and minimum temperature of $26.9^{\circ}$ and $15.3^{\circ} \mathrm{C}$, respectively with mean annual rainfall $800 \mathrm{~mm}$ [22]. Metahara Sugar Estate is located 200km south east of the capital Addis Ababa, $8^{\circ} \mathrm{N}$ latitude and $39^{\circ} 52^{\prime} \mathrm{E}$ longitude with an elevation of 950 masl. The annual mean rainfall of the area is $550 \mathrm{~mm}$ with mean annual maximum and minimum temperatures $32.8^{\circ} \mathrm{C}$ and $17.5^{\circ} \mathrm{C}$, respectively [23]. The experiment comprised one hundred seventy four local sugarcane genotypes collected from different geographic regions in Ethiopia and two hundred twenty six exotic genotypes introduced over different periods of time from many source countries (see Appendix in Supplementary Material available online at http://dx.doi.org/10.4236/ajps.2016.710139). Therefore, a total of 400 sugarcane genotypes were grown each in $5 \mathrm{~m} \times$ single row plots with $1.45 \mathrm{~m}$ spacing between rows at the two locations. Plots were planted by placing in each furrow short pieces of cane (three budded setts) with $20 \mathrm{~cm}$ spacing between setts. The experimental design was partial balanced lattice with two replications. Normal agronomical practices were practiced throughout the growth period. Data was collected on quantitative traits such as sprout counts 2 months after planting, tiller counts 4 months after planting, stalk count 10 months after planting, millable stalk count, single cane weight, number of internodes, internode length, stalk height, stalk diameter, leaf length, leaf width, leaf area, cane yield, brix percent (brix \%), pol percent (pol \%), purity percent (purity \%), sugar percent (SR \%) and sugar yield.

\section{Statistical Analysis}

Combined ANOVA was done over locations using PROC GLM procedure of SAS software V9. Pearson correlation coefficients were estimated among the variables as suggested by [24]. The total correlation coefficients of various yield contributory characters with regard to cane yield was partitioned into components of direct and indirect effects following the method adopted by [6].

\section{Results and Discussion}

The genotypes evaluated showed highly significant difference $(\mathrm{P}<0.01)$ for all quantitative traits considered (see Table 1 in Supplementary Material available online at http://dx.doi.org/10.4236/ajps.2016.710139). The variability observed among genotypes indicated the possibility to exercise simple selection in future breeding programs [26]. Variability of genotype X location in the performance of the genotypes also designated the importance of evaluating sugarcane in many locations. Other similar studies conducted on sugarcane elsewhere also attested the need to consider more locations [25]-[27].

\subsection{Correlation}

Correlation coefficients between the different pair of agronomic characters and juice quality parameters were calculated to find the relationship among the various characters studied. The values of correlation coefficient are presented in Table 1.

From Table 1 it can be seen that cane yield had a strong positive and highly significant correlation $(\mathrm{P}<0.01)$ with all the agronomic and sugar quality traits except with number of internodes and leaf width where a positive significant $(P=0.05)$ correlation coefficient was observed. Similarly sugar yield showed positive highly signifi- 
Table 1. Correlation coefficients among 18 different characters ${ }^{*}$ in 400 sugarcane genotypes grown at Wonji and Metehara 2012/ 2013.

\begin{tabular}{|c|c|c|c|c|c|c|c|c|c|c|c|c|c|c|c|c|c|c|}
\hline & 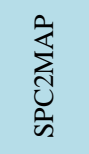 & 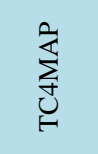 & 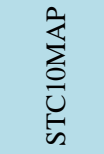 & $\begin{array}{l}\overleftrightarrow{J} \\
\text { J } \\
\sum\end{array}$ & $\underbrace{3}_{W}$ & סे & $\exists$ & 跑 & के & ב & 3 & $\leftrightarrows$ & 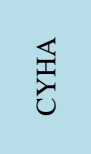 & $\begin{array}{l}\stackrel{\circ}{\circ} \\
\stackrel{x}{\bar{D}}\end{array}$ & $\frac{\stackrel{\circ}{0}}{\stackrel{0}{\circ}}$ & 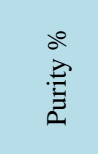 & $\begin{array}{l}\text { ○े } \\
\text { ๙ै }\end{array}$ & is \\
\hline SPC2MAP & 1.00 & & & & & & & & & & & & & & & & & \\
\hline TC4MAP & $0.36^{* *}$ & 1.00 & & & & & & & & & & & & & & & & \\
\hline STC10MAP & $0.21^{* *}$ & $0.48^{* *}$ & 1.00 & & & & & & & & & & & & & & & \\
\hline MSCHA & $0.17^{* *}$ & $0.42^{* *}$ & $0.74^{* *}$ & 1.00 & & & & & & & & & & & & & & \\
\hline SCW & $0.07^{* *}$ & $0.12^{* *}$ & $0.12^{* *}$ & $0.07^{* *}$ & 1.00 & & & & & & & & & & & & & \\
\hline NOI & -0.03 & $0.05^{*}$ & $0.08^{* *}$ & 0.02 & $0.09^{* *}$ & 1.00 & & & & & & & & & & & & \\
\hline $\mathrm{IL}$ & -0.01 & 0.004 & $0.08^{* * *}$ & $0.14^{* * *}$ & $0.14^{* *}$ & $-0.49^{* * *}$ & 1.00 & & & & & & & & & & & \\
\hline $\mathrm{SH}$ & -0.04 & $0.10^{* *}$ & $0.29^{* * *}$ & $0.37^{* *}$ & $0.47^{* *}$ & $0.23^{* *}$ & $0.33^{* *}$ & 1.00 & & & & & & & & & & \\
\hline SD & $0.07^{* *}$ & $0.08^{* *}$ & -0.02 & -0.01 & $0.56^{* *}$ & $0.07^{* *}$ & 0.04 & $0.19^{* *}$ & 1.00 & & & & & & & & & \\
\hline LL & -0.04 & $-0.06^{*}$ & -0.02 & -0.03 & $0.16^{* *}$ & $-0.07^{* *}$ & $0.07^{* *}$ & $0.10^{* *}$ & $0.09^{* *}$ & 1.00 & & & & & & & & \\
\hline LW & -0.02 & $-0.06^{*}$ & $-0.10^{* *}$ & $-0.11^{* *}$ & $0.31^{* *}$ & -0.01 & $0.07^{* *}$ & $0.08^{* *}$ & $0.33^{* *}$ & $0.24^{* *}$ & 1.00 & & & & & & & \\
\hline LA & -0.02 & $-0.07^{* *}$ & $-0.08^{* *}$ & $-0.08^{* *}$ & $0.31^{* *}$ & -0.03 & $0.08^{* *}$ & $0.11^{* *}$ & $0.29^{* *}$ & $0.65^{* *}$ & $0.88^{* *}$ & 1.00 & & & & & & \\
\hline CYHA & $0.16^{* *}$ & $0.40^{* *}$ & $0.66^{* *}$ & $0.83^{* *}$ & $0.53^{* *}$ & $0.05^{*}$ & $0.17^{* *}$ & $0.52^{* *}$ & $0.26^{* *}$ & $0.06^{* *}$ & $0.06^{*}$ & $0.09^{* *}$ & 1.00 & & & & & \\
\hline Brix\% & 0.00 & $0.06^{*}$ & $0.08^{* *}$ & $0.13^{* *}$ & $0.20^{* *}$ & 0.04 & $0.05^{*}$ & $0.21^{* *}$ & $0.19^{* *}$ & $-0.13^{* *}$ & -0.04 & $-0.10^{* *}$ & $0.20^{* *}$ & 1.00 & & & & \\
\hline Pol\% & -0.01 & 0.04 & $0.08^{* *}$ & $0.12^{* *}$ & $0.20^{* *}$ & $0.07^{* *}$ & 0.05 & $0.22^{* *}$ & $0.18^{* *}$ & $-0.13^{* *}$ & -0.04 & $-0.10^{* * *}$ & $0.20^{* *}$ & $0.96^{* *}$ & 1.00 & & & \\
\hline Purity\% & -0.03 & -0.02 & 0.03 & 0.03 & $0.09^{* *}$ & $0.12^{* *}$ & 0.02 & $0.14^{* *}$ & $0.09^{* *}$ & $-0.05^{*}$ & -0.01 & -0.03 & $0.08^{* *}$ & $0.27^{* *}$ & $0.54^{* *}$ & 1.00 & & \\
\hline $\mathrm{SR} \%$ & -0.03 & 0.02 & $0.07^{* *}$ & $0.11^{* *}$ & $0.19^{* *}$ & $0.10^{* *}$ & 0.04 & $0.23^{* *}$ & $0.17^{* *}$ & $-0.12^{* *}$ & -0.04 & $-0.09^{* *}$ & $0.18^{* *}$ & $0.89^{* *}$ & $0.99^{* *}$ & $0.67^{* *}$ & 1.00 & \\
\hline SY & $0.15^{* *}$ & $0.39^{* *}$ & $0.64^{* *}$ & $0.81^{* *}$ & $0.53^{* *}$ & $0.07^{* *}$ & $0.17^{* *}$ & $0.52^{* *}$ & $0.27^{* *}$ & 0.05 & 0.05 & $0.07^{* *}$ & $0.99^{* *}$ & $0.30^{* *}$ & $0.31^{* *}$ & $0.16^{* *}$ & $0.31^{* *}$ & 1.00 \\
\hline
\end{tabular}

SPC2MAP = Sprout count 2 months after planting; TC4MAP = Tiller counts 4 month after planting; STC10MAP = Stalk count 10 months after planting; MSCHA = Millable stalk count per hectare; SCW = Single cane weight (Kg); NOI = Number of internodes; IL = Internodes length (cm); SH = Stalk height $(\mathrm{cm}) ; \mathrm{SD}=$ Stalk diameter $(\mathrm{cm}) ; \mathrm{LL}=$ Leaf length $(\mathrm{cm}) ; \mathrm{LW}=$ Leaf width $(\mathrm{cm}) ; \mathrm{LA}=$ Leaf area $\left(\mathrm{cm}^{2}\right)$; CYHA = Cane yield $(\mathrm{qt} / \mathrm{ha})$; Brix\% = Brix percent; Pol\% $=$ Pol percent; Purity $\%$ = Purity percent; SR\% = Sugar percent; SY = Sugar yield (qt/ha); *P = 0.05, **P $<0.01$.

cant correlation with all agronomic and sugar quality traits except leaf length and width where the association was positive but non significant.

The correlation of cane yield with millable cane number and sugar yield was very strong $\mathrm{r}=0.83 * *$ and $\mathrm{r}=$ $0.99 * *$ respectively. In fact the very strong correlation of cane yield with sugar yield is expected as sugar yield is the product of cane yield and sugar percent. A positive and highly significant correlation between cane yield and its components viz single cane weight, stalk length and millable cane number was reported by [28]-[30]. [31] also observed highly significant positive correlation of cane yield with millable cane number, single cane weight, stalk height, and cane diameter.

In the present study cane yield was more closely correlated with millable cane number followed by stalk count 10 months after planting, single cane weight and stalk height. This has important implications for selection of varieties to be used as parental material for crossing purposes. The above information indicates that many of the characters affect cane yield but the degree at which each character affects yield is dependent upon the degree of association of that character to cane yield. In this case selecting for the character millable cane number would produce maximum yield as compared with any of the other characters. [1] [28] also indicated the importance of millable cane number in selection for higher cane yield. In their study [7] [9], found that cane yield was more closely correlated with stalk population than weight per stalk or stalk diameter.

A positive and significant correlation existed between millable cane number and stalk count 10 months after 
planting, followed by stalk diameter and single cane weight, stalk height and single cane weight, stalk count 10 months after planting and stalk height, stalk count 10 months after planting and single cane weight (Table 1). This indicated that selection through taller, thicker and heavier stalks would lead to increase in cane yield. [16] reported that number of millable stalks per plot and stalk diameter were the most important components of cane yield. [30] observed that millable stalks per stool and single cane weight were the most important traits influencing cane yield. [8] also demonstrated that number of millable stalks and individual cane weight made the greatest direct contribution to cane yield. But the negative association of stalk diameter with stalk count 10 months after planting and millable cane number and its positive significant association with cane yield should be treated with caution. The significant negative association of stalk diameter with millable cane number was reported [1] [17] [29]. Millable cane number was also negatively and significantly correlated with leaf width and leaf area which had positive significant association with cane yield. It had non significant negative association with leaf length. The association of millable cane number with other agronomic and sugar quality characters was positive and significant except with number of internodes and purity percent with which it had positive non significant correlation. [17] observed negative association of millable cane number with brix percent.

Knowledge of the association of various characters among themselves is important which ultimately gave the indication that selection for one trait will automatically change the other attributes. Therefore, to develop an understanding of association between the component characters is a necessary prerequisite to carry out an effective breeding program. The association between any two characters is dependent upon their inheritance. If they are inherited together, the relationship between them may be observed. The average between genes governing two or more characters, that is, location of genes on the same chromosome or chromosome governing particular character or pair is the cause for association between characters at phenotypic and genotypic levels.

Accordingly as can be observed from the present study the agronomic traits has positive significant association with cane yield, sugar yield, sugar quality parameters and with each other. Only leaf area and its component parts leaf length and width showed negative association with other yield components like sprout count 2 months after planting, tiller counts 4 months after planting, stalk count 10 months after planting, millable cane number, number of internodes, brix percent, pol percent, purity percent and sugar percent.

With regard to the biochemical characters in the present study, sugar percent was closely correlated $(\mathrm{P}<0.01)$ with pol percent, purity percent and brix percent. The three sugar quality characters also had strong positive significant $(\mathrm{P}<0.01)$ association with each other (Table 1$)$. This indicated that selection through pol percent, purity percent and brix percent would produce varieties with high levels of sucrose recovery percent [31].

\subsection{Path Coefficient Analysis}

Path analysis helps us in identifying the most important characters affecting directly and indirectly through other characters. In the present study, the path coefficient analysis was performed for cane yield as a dependent variate (Table 2). The relationship between yield and yield components may be negative or positive but it is the net result of direct effect of that particular trait and indirect effects via other traits. Hence, it is necessary to determine the path coefficients which partition the observed correlation in to direct and indirect effects and also reveals the cause and effect relationship between yield and their related traits.

Sprout counts 2 months after planting was found to have positive and considerably low direct effect on cane yield. The indirect effect of sprout count was positive through tiller number, stalk count 10 months after planting, millable cane number, single cane weight, number of internodes, stalk diameter, leaf area and brix percent.

Tiller number was observed to have negative and very low direct effect on cane yield. It had also negatively contributed to cane yield indirectly through brix percent $(-0.139)$. The direct effect was counter balanced by the positive indirect effect through millable cane number (0.812), single cane weight $(0.125)$ and pol percent $(0.201)$. Stalk count 10 months after planting showed low positive direct effect on cane yield. However, its indirect effect via millable cane number was positive and high (0.762).

Millable cane number showed the highest direct effect $(0.812)$ on cane yield. On the other hand, it had negative effect on cane yield through tiller number, number of internodes, internode length, stalk height, leaf width and brix percent. A direct effect of millable cane on cane yield was similar to the findings of [5] [8] [10] [29] [30] [32] [33].

Single cane weight had the next highest positive direct effect (0.682) on cane yield. It showed negative indirect effect on cane yield through tiller number, internodes length, stalk height, stalk diameter $(-0.174)$, leaf area 
Table 2. Path coefficients showing direct (diagonal) and indirect effects of 15 components* on cane yield.

\begin{tabular}{ccccccccccccccc}
\hline & SPC2MAP TC4MAP STC10MAP & MSCHA & SCW & NOI & IL & SH & SD & LL & LW & LA & Brix\% & Pol\% \\
\hline SPC2MAP & $\mathbf{0 . 0 3 1}$ & 0.014 & 0.052 & 0.533 & 0.138 & 0.016 & -0.001 & -0.055 & 0.016 & -0.013 & -0.012 & 0.003 & 0.031 & -0.012 \\
TC4MAP & -0.008 & $-\mathbf{0 . 0 5 4}$ & 0.066 & 0.812 & 0.125 & 0.010 & -0.003 & -0.067 & 0.054 & 0.023 & -0.020 & 0.002 & -0.139 & 0.201 \\
STC10MAP & 0.025 & -0.054 & $\mathbf{0 . 0 6 6}$ & 0.762 & 0.047 & -0.006 & -0.004 & -0.046 & 0.047 & 0.006 & -0.016 & 0.005 & -0.058 & 0.058 \\
MSCHA & 0.021 & -0.054 & 0.062 & $\mathbf{0 . 8 1 2}$ & 0.022 & -0.012 & -0.005 & -0.052 & 0.052 & 0.006 & -0.016 & 0.004 & -0.076 & 0.071 \\
SCW & 0.006 & -0.010 & 0.005 & 0.026 & $\mathbf{0 . 6 8 2}$ & 0.000 & -0.003 & -0.038 & -0.174 & 0.021 & 0.032 & -0.017 & -0.173 & 0.191 \\
NOI & 0.012 & -0.013 & -0.009 & -0.229 & -0.006 & $\mathbf{0 . 0 4 2}$ & 0.006 & 0.020 & -0.036 & -0.009 & -0.007 & 0.005 & 0.065 & -0.047 \\
IL & 0.004 & -0.023 & 0.031 & 0.507 & 0.221 & -0.031 & $-\mathbf{0 . 0 0 8}$ & -0.065 & 0.006 & 0.015 & 0.013 & -0.008 & -0.094 & 0.075 \\
SH & 0.021 & -0.046 & 0.038 & 0.529 & 0.323 & -0.010 & -0.006 & $-\mathbf{0 . 0 8 0}$ & -0.022 & 0.010 & 0.002 & -0.003 & -0.112 & 0.119 \\
SD & -0.002 & 0.014 & -0.015 & -0.205 & 0.577 & 0.007 & 0.000 & -0.009 & $-\mathbf{0 . 2 0 6}$ & 0.017 & 0.043 & -0.020 & -0.128 & 0.162 \\
LL & -0.007 & -0.022 & 0.007 & 0.089 & 0.251 & -0.007 & -0.002 & -0.014 & -0.063 & $\mathbf{0 . 0 5 6}$ & 0.014 & -0.017 & -0.050 & 0.036 \\
LW & -0.006 & 0.019 & -0.018 & -0.227 & 0.372 & -0.005 & -0.002 & -0.003 & -0.151 & 0.013 & $\mathbf{0 . 0 5 8}$ & -0.025 & -0.034 & 0.043 \\
LA & -0.004 & 0.003 & -0.011 & -0.125 & 0.404 & -0.007 & -0.002 & -0.009 & -0.148 & 0.034 & 0.052 & $-\mathbf{0 . 0 2 8}$ & -0.042 & 0.043 \\
Brix\% & -0.002 & -0.016 & 0.008 & 0.128 & 0.245 & -0.006 & -0.002 & -0.019 & -0.054 & 0.006 & 0.004 & -0.002 & $-\mathbf{0 . 4 8 4}$ & 0.546 \\
Pol\% & -0.001 & -0.020 & 0.007 & 0.105 & 0.237 & -0.004 & -0.001 & -0.017 & -0.061 & 0.004 & 0.005 & -0.002 & -0.481 & $\mathbf{0 . 5 5 0}$ \\
\hline
\end{tabular}

Residual $=0.0303 *$ SPC2MAP $=$ Sprout count 2 months after planting; TC4MAP = Tiller counts 4 month after planting; STC10MAP = Stalk count 10 months after planting; MSCHA = Millable stalk count per hectare; SCW = Single cane weight (Kg); NOI = Number of internodes; IL = Internodes length (cm); SH = Stalk height $(\mathrm{cm}) ; \mathrm{SD}=$ Stalk diameter $(\mathrm{cm}) ; \mathrm{LL}=$ Leaf length $(\mathrm{cm}) ; \mathrm{LW}=$ Leaf width $(\mathrm{cm})$ LA = Leaf area $\left(\mathrm{cm}^{2}\right)$; Brix\% = Brix percent; Pol\% = Pol percent.

and brix percent (-0.173). Its indirect effect through pol percent was positive (0.191). Significant direct effect of single cane weight on cane yield was also reported by [30]-[32].

Number of internodes showed significantly low positive direct effect on cane yield. However, it contributed to cane yield negatively through millable cane number $(-0.229)$.

Internode length showed negligible negative direct effect on cane yield. However, its indirect effect through millable cane number and single cane weight was positive $(0.507,0.221)$ respectively.

The direct effect of stalk height on cane yield was negative but low. It had positive indirect effect on cane yield through millable cane number, single cane weight and pol percent. [34] reported similar results.

Stalk diameter was found to have negative effect on cane yield directly and indirectly through millable cane number. This was counter balanced by single cane weight and pol percent. Similarly, [34] [35] showed the negative direct effect of stalk diameter on cane yield. Contrary to the present finding [33] reported stalk diameter exerting direct effect on cane yield which was positive and markedly high.

Leaf length and width showed positive direct effect on cane yield whereas leaf area showed negative direct effect. The positive indirect effect of all the three traits through single cane weight was moderately higher. Leaf width and leaf area had negative effects through millable cane number and stalk diameter.

Brix percent showed negative direct effect on cane yield, whereas pol percent had a moderate direct positive effect on cane yield. This is in agreement with the findings of [34].

The traits which had highly significant positive association and negative direct effects on cane yield were viz., tiller count, internode length, stalk height and diameter, leaf area and brix percent. Negative direct effects of positively correlated characters with cane yield were also reported by [36]. This indicates that these can be considered as selection criterion for improvement in cane yield.

\section{Conclusion}

Correlation and path analysis revealed that millable cane number and single cane weight followed by pol percent were the most important for cane yield improvement. The three characters had highly significant positive correlation with each other and with cane and sugar yield. Selection based on these characters can increase both cane 
and sugar yield. However, stalk diameter and brix percent had considerable negative direct effects on cane yield and indirect positives effect through single cane weight. Therefore, in view of their significant positive association with cane yield, during selection indirect effects of stalk diameter and brix percent via single cane weight should be considered.

\section{Acknowledgements}

The authors are grateful to the financial grant of the Sugar Corporation of Ethiopia. Many thanks are forwarded to Ethiopian Biodiversity Institute (EBI) for its technical advice during collection of the local sugarcane genotypes. Warmly gratitude goes for Dr. Hussien Mohamad at Hawassa University for his overall help and his interest and appreciation of the study. The staff and laboratory technicians at Wonji and Metehara, Sugar Corporation, Research and Training are duly acknowledged for their supports.

\section{References}

[1] Chaudhary, R.R. and Joshi, B.K. (2005) Correlation and Path Coefficient Analyses in Sugarcane. Nepal Agricultural Research Journal, 6, 24-27.

[2] Swaminathan, M.S. (1991) Biodiversity and Sustainable Agriculture: Look at This Way. Outlook Agriculture, 20, 3-4.

[3] Esayas, T. ( 2014) Exploration and Collection, Characterization, Genetic Diversity Analysis and Association of Traits for Yield and Yield Components of Sugarcane (Saccharum spp.) in Ethiopia. PhD Dissertation, Haramaya University, Dire Dawa.

[4] Kang, M.S., Zuber, M.S. and Krause, G.F. (1983) Path Coefficient Analysis of Grain Yield and Harvest Grain Moisture in Maize. Tropical Agriculture (Trinidad), 60, 253-256.

[5] Kang, M.S., Sosa, O. and Miller, J.D. (1989) Path Analysis for Percent Fiber and Cane and Sugar Yield in Sugarcane. Crop Science, 29, 1481-1483. http://dx.doi.org/10.2135/cropsci1989.0011183X002900060032x

[6] Dewey, D.R. and Lu, K.H. (1959) A Correlation and Path Coefficient Analysis of Components of Crested Wheat Grass Seed Production. Agronomy Journal, 51, 515-518. http://dx.doi.org/10.2134/agronj1959.00021962005100090002x

[7] Hogarth, O.M. (1971) Quantitative Inheritance Studies in Sugarcane: Correlations and Predicted Responses to Selection. Australian Journal of Agricultural Research, 22, 103-109. http://dx.doi.org/10.1071/AR9710103

[8] Chaudhary, A.K. and Singh, J.R.P. (1994) Correlation and Path Coefficient Studies in Early Maturing Clone of Sugarcane (Saccharum spp. Complex). Cooperative Sugar, 25, 305-307.

[9] James, N.I. (1971) Yield Components in Random and Selected Sugarcane Populations. Crop Science, 11, 906-908. http://dx.doi.org/10.2135/cropsci1971.0011183X001100060043x

[10] Hussein, M.A.S., Fateh, H.S., Fares, W.M. and Attaya, A.S. (2012) Multivariate Analysis of Sugarcane Yield Factors in Sugarcane. American Eurasian Journal of Sustainable Agriculture, 6, 44-50.

[11] Abdelmahmoud, O.A., Ahmed, O. and Basil, D. (2010) The Influence of Characters Association on Behaviour of Sugarcane Genotypes (Saccharum spp.) for Cane Yield and Juice Quality. World Journal of Agriculture Science, 6, 207211.

[12] Terzi, F.S.P., Rocha, F.R., Vencio, R.Z.N., Felix, J.M., Branco, D.S., Waclawovsky, A.J., et al. (2009) Sugarcane Gene Associated with Sucrose Content. Genomics, 10, 1471-2164.

[13] Zhu, Y.J., Albert, H.H. and Moore, P.H. (2000) Differential Expression of Soluble Acid Invertase Genes in the Shoots of High-Sucrose and Low-Sucrose Species of Saccharum and Their Hybrids. Australian Journal of Plant Physiology, 27, 193-199.

[14] Chaudhry, B.A. (1982) Fertilizer and Dolomitic Lime Requirements of Some Sugarcane Soil in Negros Occidental, Philippines. PhD Dissertation, University of Philippines, Los Banos.

[15] Raman, K., Bhat, S.R. and Tripathi, B.K. (1985) Ratooning Ability of Sugarcane Genotypes under Late Harvest Conditions. Indian Sugar, 35, 445-448.

[16] Singh, H. and Sharma, H.L. (1983) Path Coefficient Analysis of Cane Yield in Sugarcane. Indian Sugar Crops Journal, 9, 7-9.

[17] Khan, K.A. (1995) Studies on Association among Yield and Quality Character in Advanced Clones in Sugarcane. MSc Thesis, GB Pant University of Agriculture and Technology, Pantnagar.

[18] Liu, M.C., Yeh, H.S. and Chen, W.H. (1984) A High-Sucrose and Vigorously Growing Calliclone 71-4829. Report of Taiwan Sugar Research Institute, 102, 1-11.

[19] Bull, T. (2000) The Sugarcane Plant. In: Hogarth, M. and Allsopp, P., Eds., Manual of Cane Growing, Bureau of Sugar Experimental Stations, Indooroopilly, 91-108. 
[20] Petrasovits, L.A., Purnell, M.P., Nielsen, L.K. and Brumbley, S.M. (2007) Production of Poly Hydroxy Butyrate in Sugarcane. Plant Biotechnology Journal, 5, 162-172. http://dx.doi.org/10.1111/j.1467-7652.2006.00229.x

[21] Risch, N.J. (2000) Searching for Genetic Determinants in the New Millennium. Nature, 405, 847-856. http://dx.doi.org/10.1038/35015718

[22] Darvasi, A. and Pisanté-Shalomm, A. (2002) Complexities in the Genetic Dissection of Quantitative Trait Loci. Trends in Genetics, 18, 489-491. http://dx.doi.org/10.1016/S0168-9525(02)02767-1

[23] Ethiopian Sugar Development Agency (ESDA) (2009) Performance Report. Proceedings of Ethiopian Sugar Industry Biennial Conference, Vol. 1, Adama, 23-24 September, 186-197.

[24] Steel, R.G.D. and Torrie, J.W. (1980) Principles and Procedures of Statistics with Special Reference to the Biological Science. McGraw Hill Book Company Inc., New York.

[25] Punia, M.S. (1982) Studies on Variability, Heritability and Genetic Advance of Some Quality Attributes in Sugarcane. Indian Sugar, 31, 911-914.

[26] Khan, I.A., Khatari, A., Siddiqui, M.A., Nizamani, G.S. and Raza, S. (2004) Performance of Promising Sugarcane Clones for Yield and Quality in Different Ecological Zones of Sindhi. Pakistan Journal of Botany, 36, 83-92.

[27] Chang, Y.S. (1996) Estimating Heritability and Correlations among Brix, Purity and Sugar Content in Sugarcane Using Balanced Multiple Location and Year Data. Report of Taiwan Sugar Research Institute, 151, 1-10.

[28] Brown, A.H.D., Daniels, J. and Latter, B.H.D. (1969) Quantitative Genetics of Sugarcane: Correlation Analysis of Continuous Character in Relation to Hybrid Sugarcane Breeding. Theoretical Applied Genetics, 39, 478-481. http://dx.doi.org/10.1007/BF00283078

[29] Balasundaram, N. and Bhagyalakshmi, B. (1978) Variability, Heritability and Association among Yield and Yield Components of Sugarcane. Indian Journal of Agricultural Science, 48, 291-295.

[30] Punia, M.S., Paroda, R. and Hooda, R.S. (1983) Correlation and Path Analysis of Cane Yield in Sugarcane. Indian Journal of Genetics and Plant Breeding, 43, 109-12.

[31] Tyagi, A.P. and Lal, P. (2007) Correlation and Path Coefficient Analysis in Sugarcane. South Pacific Journal of Natural Science, 25, 1-9. http://dx.doi.org/10.1071/SP07001

[32] Chaudhary, R.R. and Bal, K.J. (2005) Correlation and Path Coefficient Analyses in Sugarcane. Nepal Agricultural Resource Journal, 6, 24-27.

[33] Kumar, S. and Kumar, D. (2014) Correlation and Path Coefficient Analysis in Sugarcane Germplasm under Subtropics. African Journal of Agricultural Research, 9, 148-153. http://dx.doi.org/10.5897/AJAR2013.7071

[34] Tahir, M., Iftikhar, H.K., McCord, P.H. and Barry, G. (2014) Character Association and Selection Indices in Sugarcane. American Journal of Experimental Agriculture, 4, 336-348. http://dx.doi.org/10.9734/AJEA/2014/6086

[35] Smiullah, F., Usman, A.K. and Ijaz1, A. (2013) Genetic Variability of Different Morphological and Yield Contributing Traits in Different Accession of Saccharum officinarum L. Universal Journal of Plant Science, 1, 43-48.

[36] Patel, M.M., Patei, H.S., Patel, A.D. and Patel, M. (1993) Correlation and Path Analysis in Sugarcane. Indian Sugar, 43, 365-368.

\section{Submit or recommend next manuscript to SCIRP and we will provide best service for you:}

Accepting pre-submission inquiries through Email, Facebook, LinkedIn, Twitter, etc.

A wide selection of journals (inclusive of 9 subjects, more than 200 journals)

Providing 24-hour high-quality service

User-friendly online submission system

Fair and swift peer-review system

Efficient typesetting and proofreading procedure

Display of the result of downloads and visits, as well as the number of cited articles

Maximum dissemination of your research work

Submit your manuscript at: http://papersubmission.scirp.org/ 